\title{
On the appraisal and development of ST-X field: uncertainties and challenges
}

- Vu Viet Hung

Lam Son Joint Operating Company

- Mai Cao Lan

University of Technology, VNU-HCM

Adjunct Senior Lecturer, University of Southern Queensland, Australia

(Manuscript Received on August 19 ${ }^{\text {th }}, 2014$; Manuscript Revised November 11 $1^{\text {th }}, 2014$ )

\begin{abstract}
:
This paper summarizes theuncertainties and challenges in appraising and developing the ST-X gas condensate field, which is offshore Vietnam in Block 15-1. Drill Stem Test (DST) results show that the ST-X field has moderate to low permeability, multiple flow boundaries/barriers, and at least 2 $P V T$ regions. To understand the impact of these and other important reservoir parameters on ultimate gas and condensate recovery and well count, a reservoir simulation study was performed. The study demonstrates that there is a wide range
\end{abstract}

of possible ultimate gas and condensate recoveries and well counts. The top causes for this wide range are the heterogeneity in permeability distribution and flow boundaries/barriers. In addition to the subsurface risks, drilling cost of a $S T-X$ well is very high. The high well cost in combination with the field being offshore, having low permeability and possibly numerous reservoir compartments dramatically increase the risk of a full field development.

Keywords: Uncertainty assessment, Reservoir simulation, Field development.

\section{INTRODUCTION}

The ST-X field is in the Cuu Long basin with approximately $155 \mathrm{~km}$ east of Vung Tau, $62 \mathrm{~km}$ offshore Vietnam, in 66 meters of water. Four wells have been drilled in the ST-X field to date (Figure 1). The first wildcat well,Well-Alies in the South East corner of Block 15-1O. Tests showed hydrocarbons flowing from three intervals in the Oligocene Clastics. The second well (or the first appraisal well) Well-Bwas drilled to evaluate the faulted and fractured basement reservoir, as well as, the Oligocene sandstones sequences.

The second appraisal well,Well-Cwas drilled to evaluate the down flank extent of the sand sequences and an untested fault block. The Well-Dwell was drilled to test the Oligocene clastics on the northern flank of the ST-X structure.

\section{APPRAISAL WELLS RESULTS}

DST's were conducted on the Well-A(D, E and F Sand); Well-B(Basement); Well-C(E and F Sand) and Well-D(E sand)wells. Table 1 summarizes the flow properties determined from these tests for each well and sand sequence.In addition to the PVT data obtained from the DST's (Table 2), MDT data also provides an understanding of how the PVT properties may vary within the reservoir (Figure 2). They indicate that potentially three PVT regimes may exist in the field.

\section{Trang 110}




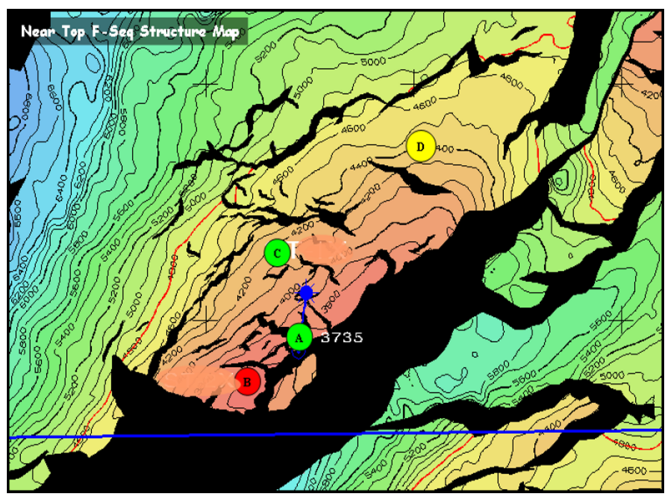

Figure 1. ST-X Wells Location

Table 1. Flow Properties Seen on DST's

\begin{tabular}{|c|c|c|c|c|}
\hline & Well / DST & Perm & $\begin{array}{l}\text { Pressure } \\
\text { drop }\end{array}$ & Remark \\
\hline \multirow{2}{*}{ Well-A } & $\begin{array}{c}\text { DST\#2 } \\
\text { F sequence }\end{array}$ & High & Small & Boundary effected \\
\hline & $\begin{array}{c}\text { DST\#3 } \\
\text { E sequence }\end{array}$ & High & Small & Boundary effected \\
\hline Well-B & $\begin{array}{c}\text { DST\#2 } \\
\text { Basement }\end{array}$ & Very Low & & $\begin{array}{l}\text { Pressure on trend with overlying } \\
\text { F sand. Very low Perm }\end{array}$ \\
\hline \multirow{2}{*}{ Well-c } & $\begin{array}{c}\text { DST\#1 } \\
\text { F sequence }\end{array}$ & Very Low & Large & Boundaries effected \\
\hline & $\begin{array}{c}\text { DST\#2 } \\
\text { E sequence }\end{array}$ & Very Low & Large & Condensate Blockage \\
\hline Well-D & $\begin{array}{c}\text { DST\#2 } \\
\text { E sequence }\end{array}$ & Very Low & Large & Boundaries effected \\
\hline
\end{tabular}

Table 2. PVT Data Obtained From Exploration / Appraisal Wells

\begin{tabular}{|c|c|c|c|}
\hline Well & Formation & Fluid & Pb/Pd \\
\hline Well-A & E & Gas & $\sim 4800$ \\
\hline Well-B & Basement & Gas & $\sim 4200$ \\
\hline Well-C & E & Gas & $\sim 7600$ \\
\hline Well-C & F & Gas & $\sim 5000$ \\
\hline Well-D & E & Liquid & $\sim 7100$ \\
\hline
\end{tabular}

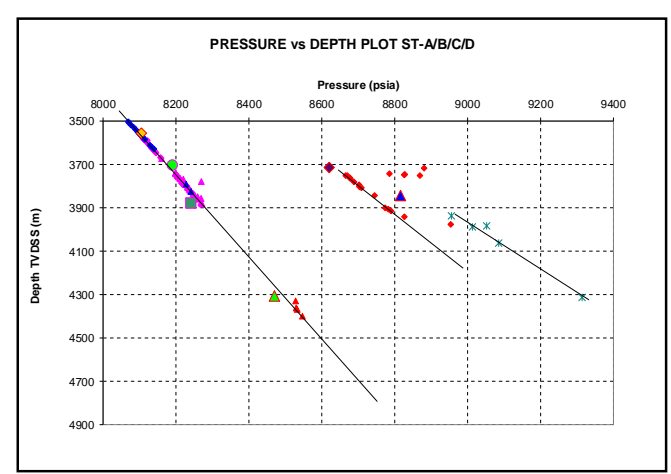

Figure 2. MDT Data Obtained From ST Exploration / Appraisal Wells 
The results from the DST's performed on the exploration and appraisal wells indicate that the permeability and reservoir connectivity of ST-X is considered to be low to moderate. An example of drawdown and build-up data from a DST performed on a ST-X appraisal well is shown in Figure 3. The final build-up pressure was lower than the initial pressure for all DST's. This pressure drop is an indicator of a relatively low permeability reservoir system with possible boundaries. All DST's wereshown to be affected by late time boundary effects from pressure transient analysis. The final build up pressure being lower than the initial pressure for all DST's was interpreted as restricted flow barriers and/or significant reductions in permeability with increasing distance from the wells (condensate blockage was observed occurring on one DST as the bottom hole flowing pressure (Pwf) dropped below the dew point pressure $(\mathrm{Pd}))$.

The pressure derivative response formost of the DST's indicates early time pseudo radial flow followed by a continuously increasing pressure derivative.An increasing derivative is a result offlow barriers or the permeability decreasing with an increasingarea of investigation. This pressure derivative response can be modeled with either parallelno flow boundaries at relatively close distances to the well or a radial composite system. The calculatedkh for both the $\mathrm{E}$ and F sequences were generally low except for the crestal area. The DST'sindicate that permeability tends to decrease with increasing depth (lower in the flanks, moderate to high in the crest).

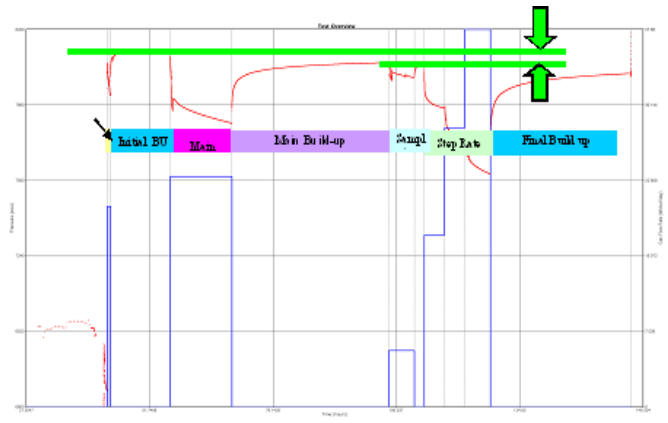

Figure 3. Reservoir Pressure drop during DST period.

The largest uncertainty from the interpreted DST results was thenature of the boundary effectsobserved from all thepressure versus time data. Although some faulting is evident from seismic, it is difficult to interpret faults as near to the well as the boundarydistances calculated from pressure transientanalyses. A possible geologic explanation is that the "boundaries" seenby the DST pressure response may be a result of diagenesis occurring at channel boundaries. Theseboundaries reduce theaerial flow capacityto the wellbores and appear as boundaries on the DST pressure responses. None of the wells, except possibly the Well-D well, flowed under boundary dominated flow conditions (depletion), so the sizes of the field's reservoir compartments are still unknown. The number and flow capacity ofthe flow boundaries could not be determined from these short term DST's. This uncertaintymakes it difficult to determine the long term production forecasts for future development wells.

To sum up, the most critical uncertainties relating to reservoir performance and ultimate recovery have been identified as (a) Permeability distrubtion/absolute values/variation with depth; (b) Reservoir connectivity/boundary effects; and (c) Impact of condensate blockage.

\section{IMPACT OF RESERVOIR UNCERTAINTIES}

This section studies and dciscusses the impact of the previously-identified reservoir uncertainties upon well performance, recovery factor, and well count through the use of reservoir simulation. First, a base reservoir simulation model was generated for the entireST-X field. Then, several reservoir models were generated to verify and rank the key uncertainties and derive a range ofpotential reserves outcomes.

\section{Base Reservoir Simulation Model: Inputs}

The full field reservoir simulation model was created by upscaling the fine scale geological model which was created in the Roxar RMS modeling package. The fine scale grid size of $50 \times 50 \times 1 \mathrm{~m}$ cells was upscaled to 200 x 200 x 5m cells to reduce the reservoir simulation run times. Figure 4 showsthe $3 \mathrm{D}$ view of the coarse scale model.

In addition to the static reservoir parameters used to populate the geologic model (e.g. porosity, permeability,net/gross ratio, water saturation), all available dynamic data such as fluid contacts (both gaswater and gas-oil contacts), PVT, and SCAL test

\section{Trang III}


information $(\mathrm{Pc}, \mathrm{Cr}, \mathrm{Kg} / \mathrm{Ko}$ ) were included in all of the fine and coarse scaled models.

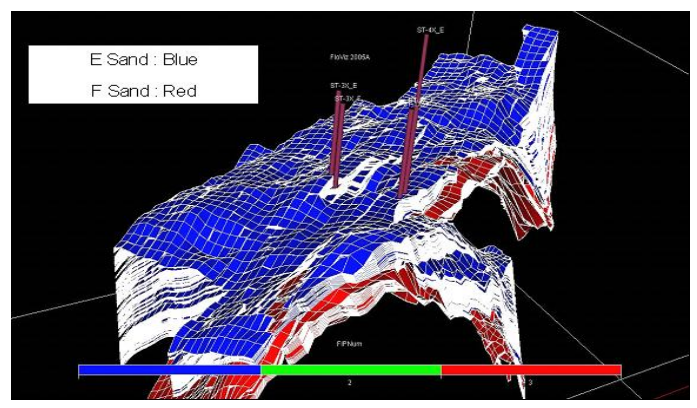

Figure 4.3D View of Simulation Model

\section{Base Reservoir Simulation Model: Model Tuning to DST Results}

As discussed earlier, DST results show that flow boundariesexist atrelatively close distances from the exploration and appraisal wells.Moderate to low

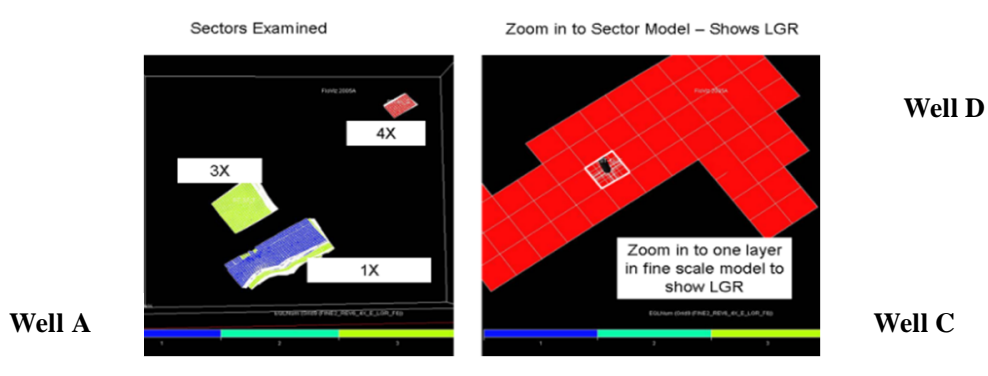

effective permeability was also calculated from these tests. In addition, condensate blockage will occur in this field when the wells bottom hole flowing pressure drops below the dew point. Condensate blockage was observed on one test. To properlysimulatethe flow effects that were measured from the DST's, fine scale sector models were cut from the fine scale geologic model for each well that flow tested either the $\mathrm{E}$ or $\mathrm{F}$ sands. The grid size dimensions of the fine scale simulation models are typically $50 \times 50 \times 1 \mathrm{~m}$. Local grid refinement (LGR) was used to further capture near wellbore pressure and relative permeability effects that may have affected the pressure versus time behavior of the DST's. Each sector model was used to match pressure versus time behavior of the DST flow tests. An illustration of the fine scale sector models used for each well and the LGR used for matching the DST's is shown in Figure 5.

Figure 5. Fine scale sector models and local grid refinement

Each sector model was then used to history match the pressure versus time behavior of the DST's by varying perme ability and the transmissibility multipliers (represents the flow boundaries). After matching the DST's, a production forecast was made for each well. This forecast was used to compare with the coarse scale model forecasts for each well. Figure 6 shows the history match made for both the fine and coarse scale models.

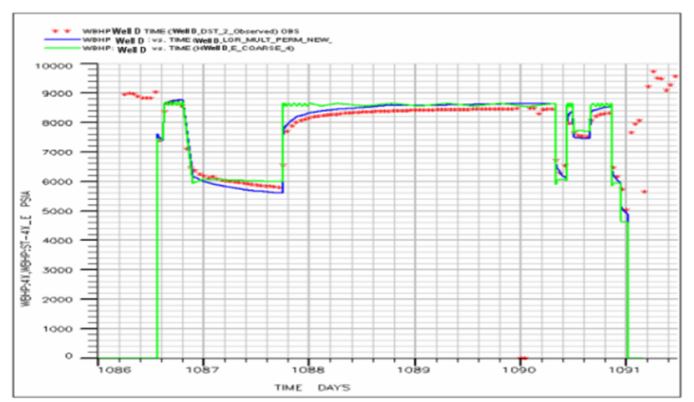

Figure 6. History Matching Results

To properly compare the fine and coarse scale model forecasts, they first need to have the same hydrocarbon pore volume. Production forecasts for the coarse and fine scale sector models for each DST were then run and compared to ensure both models gave the same production forecast. In all cases the effective permeabilities and transmissibility modifiers in the coarse scale sector model needed to be altered to get a match.The matched coarse and fine scale model forecasts is shown in Figure 7. 


\section{Sensitivity Studies to Rank Key Reservoir Uncertainties}

As previously discussed, the DST results show significant reservoir uncertainties exist for the ST-X field. The critical ones relating to reservoir performance and reservoir recovery factor have been identified below:

- Permeability distribution/ absolute values /variation with depth;

- Reservoir connectivity / boundary effects;

- $\quad$ Impact of condensate blockage.

To understand the impact of these uncertainties on ultimate recovery and well count, multiple sensitivities were run with the low, base, and high case models created for each parameter change [1]. The impact of various uncertainties on well countgenerated from these models is show in Figure 8.

A tornado diagram showing the impact of each parameter to ultimate recovery and well count is shown in Figure 9. It can be seen from the sensitivity analysis that the most significant reservoir parameters affecting well count and recovery factor are permeability and flow boundaries/barriers.

The short term DST's performed on the exploration and appraisal wells did not have enough test time to better understand the permeability variation and nature of the flow boundaries. A long term production test is necessary to more fully understand the reservoir permeability and flow boundaries aerial and vertical distributions.

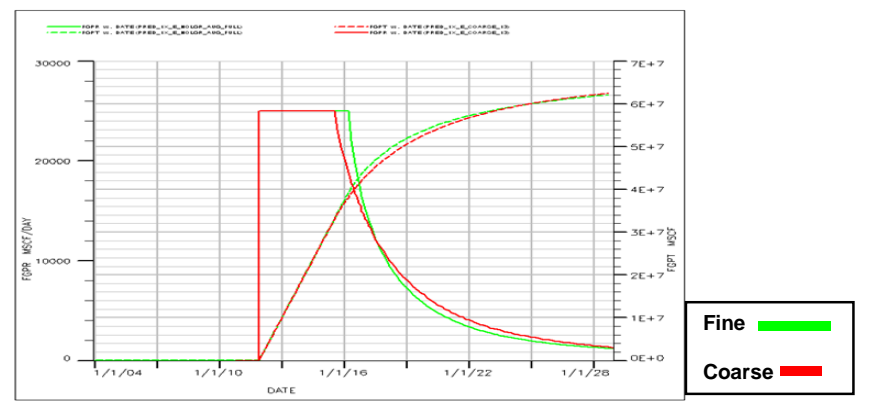

Figure 7. Matching Fine Scale to Coarse scale production forecasts

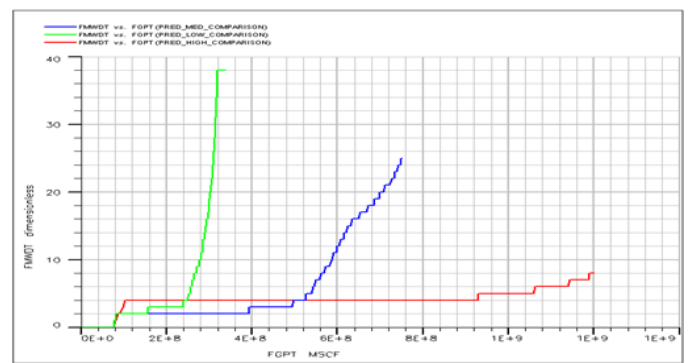

Figure 8. Impact of uncertainties on well count

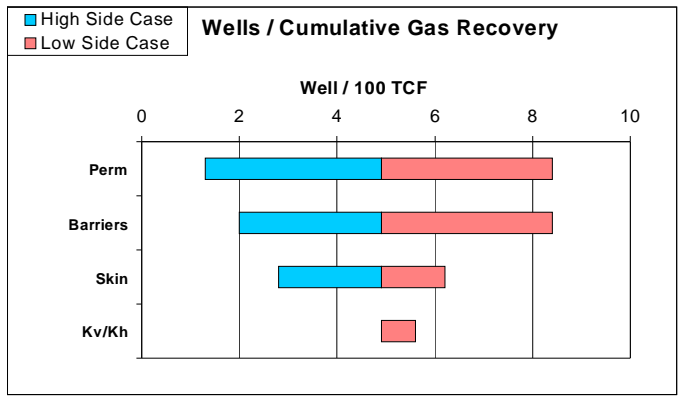

Figure 9. Impact of uncertainties on well count (Recovery Factor)

\section{Trang 114}




\section{POTENTIAL RANGE OF RECOVERY FACTORS}

Recovery factors were calculated for all of the forecasts generated for the sensitivity study[2].Following is a description of the reservoir parameters used for the base, high, and low simulation models created for the sensitivity cases.

In addition to the reservoir parametersdescribed above, commercial and economic factors also affect recovery factors. A range of potential development scenarioswere considered to help derive a range of potential recovery factors[3]. Figure 10 summarizes the range of recovery factorsdetermined from the forecasts generated from thesimulation study taking into account both technical and economic considerations[4].

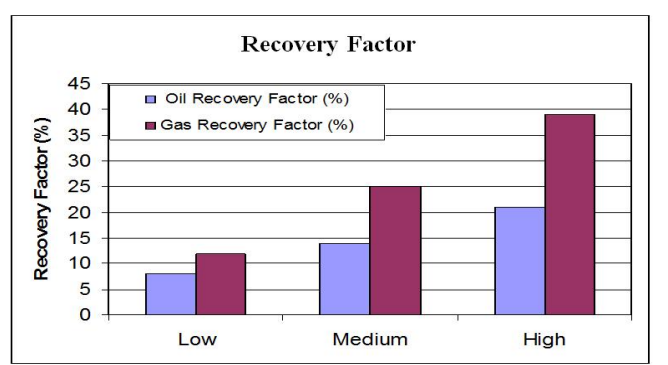

Figure 10. Recovery Factor Estimation (Low,Base, and High Cases)

\section{CONCLUSIONS}

Theresults of this work show that there remains significant reservoir uncertainties in the ST-X field and thesimulated recovery factor can vary greatly. The well count forthe good reservoir permeability and connectivity scenario is much lower than for the case where the reservoir has poor permeability and connectivity.Additionally, during the exploration and appraisal phase of the ST-X field, it was found that the drilling cost of a ST-X wells are very high. The high drilling cost combined with the field being offshore and the reservoir having both low permeability and potentially large numbers of reservoir flow boundaries make a full field development a high risk endeavor.

For these reasons an Early Production Systemis recommended to reduce the development risk. In addition to generating revenue by selling the produced condensate and gas, the production data will improve the understanding of the field'spermeability distribution and connectivity. The reservoir information obtained from the Early Production System will be vital input for furtherconsideration of a full field development plan ofST-X Field.

\section{Thẩm địa và phát triển mỏ ST-X: các yếu tố không chắc chắn và những trở ngại}

- Vũ Việt Hùng

Công ty Lam Sơn

- Mai Cao Lân

Trường Đại học Bách Khoa, ĐHQG-HCM

Đại học Qeenland, Úc

\section{TÓM TÁT:}

Bài viết này đề cập tới những bất ổn và trở ngại trong việc thẩm định và phát mỏ khí ST-X ngoài khơi Việt Nam tại Block 15-1. Kết quả phân tích Drill Stern Test (DST) cho thấy mỏ ST-X có độ thấm trung bình và thấp, nhiều biên giới dòng chảy và rào cản, và ít nhất 2 vùng $P V T$. Để hiểu được ảnh hưởng của các tính chất này cũng như của các thông số vỉa quan trọng khác tới khả năng thu hồi khí, một nghiên cứu sử dụng mô phỏng vỉa đã được thực hiện. Kết quả cho thấy rằng khả năng thu hồi có thể biến đổi trên diện rộng. Nguyên nhân của sự biến đổi lớn này là do tính không đồng nhất của độ thấm cũng như của các biên giới dòng chảy/rào cản.Bên cạnh những rủi ro có thể gặp 
phải trong vỉa thì chi phí khoan giếng ST-X là rất cao. Chi phí cao kết hợp với việc mỏ ở ngoài khoi, tăng đáng kể các nguy cơ có thể gặp phải khi phát độ thấm thấp và có thể có nhiều khoang chứa làm triển mỏ.

Từ khóa: Đánh giá sự không chắc chắn, Mô phỏng vỉa, Phát triển mỏ.

\section{TÀI LIỆU THAM KHẢO}

[1]. D. C. Montgomery, Design and Analysis of Experiments, John Wiley \& Sons, 2001.

[2]. C. P. D.J.schoizer, "Use uncertainty analysis to improve production history matching and decision make process," SPE 99324, 2006.
[3]. F. Friedmann, A. Chawathé, D. K. Larue, "Assessing Uncertainty in Channelized Reservoirs Using Experimental Designs," SPE 71622, 2001.

[4]. B. Yeten, "A Comparision Study On Experimetal Design and Response Surface Methodologies," SPE 993347, 2005.

\section{Trang 116}

